\title{
Strip-Searching: Stop the State's Sexual Assault of Women in Prison \\ Debbie Kilroy
}

\section{Women Prisoners and Sexual Abuse}

\section{Case 1}

When Mary was eight years old her stepfather Donald began sexually abusing her. She became withdrawn, secretive, and uncooperative. Her performance at school declined. Eventually, when she was twelve years old, the abuse was revealed and Mary was removed from her family and placed in the care and control of a church-run orphanage. The priest in charge of the orphanage raped her and threatened her with punishment if she disclosed his crime.

Thirty years later the priest was tried and convicted of Mary's rape.

The community was rightly outraged that any child should be subjected to such abuse. Everybody from the prosecuting lawyers to the sentencing judge to the newspaper editorials and letters to the editor said the enormity of the priest's crime was not only that he used his position of authority to abuse a child, but that the child was particularly vulnerable. This child needed special care and attention to help deal with her stepfather's abuse, but instead was subjected to cruel, inhuman, and degrading treatment. She was raped again when she should have been made safe.

\section{Case 2}

Jane does not remember her natural father. She was nine months old when he left her mother. When Jane was two years old her mother's de facto husband Wayne moved in to live with them. Almost immediately Wayne began sexually abusing Jane. It started as fondling, and Wayne inserting his finger in Jane's vagina. As Jane approached puberty, she was required to parade naked for Wayne and perform oral sex on him. By the time Jane was eleven years old Wayne was regularly raping her.

Jane's behaviour was sullen, uncooperative, and abusive. She repeatedly failed school assessments. When Jane went to high school she made friends with two girls who could get drugs from their brothers. She began to medicate herself to obliterate the knowledge of Wayne's abuse. She would use anything - alcohol, speed, cannabis, heroin. 
Jane began stealing handbags from shopping trolleys, shoplifting, and selling speed to fund her own drug habit. On three occasions Jane was arrested and charged with multiple dishonesty offences. On the first occasion she was placed on probation for eighteen months, but received no drug counselling. On the second occasion, which was within the period of probation, she was sentenced to two years imprisonment wholly suspended. Again, she received no drug counselling. On the third occasion, which constituted a breach of the suspended sentence, she was given a custodial sentence.

Her mother came to visit her soon after she was jailed. After the visit, Desley, a correctional officer, told Jane to take her clothes off piece by piece and hand them over. Desley told Jane to turn around slowly in front of her with her arms spread out and then to face her and lift her breasts with her hands. Jane was then told to turn round, stand with her legs apart, bend over and spread her buttocks apart with her hands. When Desley told Jane to squat, she noticed the cord from Jane's tampon and told her to remove the tampon while she watched. Then Jane was told to cough.

Jane's heart was pounding. Her throat was dry. She felt she could not swallow, but there was a large lump in her throat which was choking her. She felt cold, but her hands were sweaty. It seemed like she could not see properly. The world closed in. All she could see was Wayne demanding she "do her strip show" before he raped her. She wanted to throw up. She desperately needed a fix.

Desley told Jane that she will be strip-searched after every visit, even visits by her lawyer.

\section{Case 3}

Amanda is in prison for embezzlement. She is smart and stands up for herself. She is enrolled as an external student in a university course. Gary is a middle-aged male correctional officer. He did not complete high school. Gary resents the fact that Amanda is articulate, rational, and better educated than him. Brian is another male correctional officer. He is in his twenties and "has tickets on himself." He also resents Amanda because she jeered at him when he suggested he could do her favours in return for oral sex.

Gary and Brian escort Amanda to attend her mother's funeral. On the way back to the prison, they both rape her "to teach her a lesson." 


\section{What Is Sexual Assault?}

No one has any difficulty in recognizing the actions of Donald, the priest, Wayne, Gary, and Brian as criminal sexual assaults. No one has any difficulty in recognizing their actions as an abuse of power, a betrayal of positions of trust and authority, and a gross breach of a duty of care.

Yet who perceives Desley's actions as sexual assault, abuse of power, betrayal of trust, and gross negligence, all approved and encouraged by the state? Who understands Jane's experience as revictimization? Who recognizes that Jane is sexually assaulted by the state? ${ }^{1}$

\section{Arguments against Strip-Searching}

Strip-searches rarely uncover contraband being smuggled into prison. But by the very fact of their degrading and humiliating impact on women prisoners, strip-searches are a very powerful weapon of social control used by the state.

The state tries to deny that strip-searches are criminal assaults by justifying them for a variety of purposes, by labelling the victims as a class deserving of the treatment, and by completely ignoring the experiences of the victims. The state goes to great lengths to justify its powers over women prisoners precisely because it knows that these actions are criminal. ${ }^{2}$

1 This argument was also made in Canada by feminist and prisoners' rights organizations in the aftermath of the actions of the Institutional Emergency Response Team in the segregation unit of the federal Prison for Women in Kingston, Ontario, in April 1994. As per policy, officers videotaped the event, which included footage of male officers ordering and participating in the strip-searching of women prisoners in segregation, waking some of them from sleep in order to do so. The Canadian Broadcasting Corporation later managed to access this tape through a court challenge and broadcasted it on the national television newsmagazine show "The Fifth Estate" the following year. The government then established a Commission of Inquiry into Certain Events at the Prison for Women in Kingston, and appointed the Honourable Louise Arbour as its Commissioner. Arbour was later named the Chief Prosecutor for the International Criminal Tribunal for war crimes in the former Yugoslavia and Rwanda, and is currently a Justice of the Supreme Court of Canada. The report of the Commission (1996) was published by Public Works and Government Services Canada and can be obtained at Canada Communications Group - Publishing, Ottawa, Canada K1A 0S9.

2 Amanda George, "Strip Searches: Sexual Assaul by the State" in Easteal, P. (ed.), Without Consent: Confronting Adult Sexual Violence, p. 212. Australian Instinte of Criminology. Conference Proceedings, 27-29 October 1992. 
Strip-searches of prisoners are justified on the basis of keeping the prison drug free. It is interesting to note that the records, obtained by Sisters Inside through Freedom of Information (FOI), state that for the twelve months beginning August 1999, 12,136 searches were conducted on women in Brisbane Women's Correctional Centre. Of these searches 5,346 were full body stripsearches, one of which was conducted on a baby. The latest FOI records state that there have been 17,191 searches with 8,408 full-body strip-searches conducted in the 24 months from August 1999 to August 2001.

According to the Department, visitors pass illicit drugs to prisoners. Since strip-searches have been conducted as a matter of mandatory practice under the Corrective Services Act (2000) after all visits (including legal visits when the prison first opened) in the new women's prison at Wacol, the contraband recorded were two cigarettes, earrings, sanitary pad (no blood), and a "scratch from the window to the door and a foul odour."

It is difficult to understand how the pad, the scratch, and the foul odour can be considered contraband, but Corrective Service records have identified them as such. In spite of the comprehensive practice of strip-searching, drugs still get into the prison. Furthermore, it was noticed that in the last twelve months of the strip-searching records, the number of searches has decreased by half. This is due to women asking that their children and families not visit them because they cannot face being sexually assaulted via the mandatory strip-search after family visits.

In a recent survey of women in prison, 51 percent state that they are still using drugs within the prison and 84 percent say they are receiving no counselling or support to assist them with their drug abuse. ${ }^{3}$

The Department of Corrective Services is not keen to investigate a major route of drugs into jail: corrupt correctional officers. Until July of last year there was legislation in place that allowed searching of cars, bags, and clothing of correctional officers as well as their person; however, in the new Corrective Services Act, enacted in July 2001, this power has been removed.

Prisoners are strip-searched because it is a highly effective way to control women, not because it keeps the drugs out of prison. It is obvious from evidence about drug use in the wider community and within prisons that 
repressive regimes simply do not work. The mainstream debate in the wider community is about addressing the demand for drugs, not the supply. The emphasis should be focused on the reasons why women use drugs rather than physically trying to prevent the use of drugs. Strip-searching as a mechanism for ridding drugs from prison is a demonstrated failure. The wider society moves on, but the philosophy of corrections is returning to the nineteenth century.

\section{Strip-Searching as a Form of Assault}

The criminal character of strip-searching that is conducted randomly (that is, searches conducted without specific reasonable suspicion about the person about to be searched) or as a matter of routine is appreciated in the context of the law of assault. Assault is the application of force to a person without their consent and includes the person's reasonable fear that force will be applied to them. An act that might otherwise be regarded as an assault is no longer unlawful if there are circumstances that the law recognizes as justifying the use of "reasonable force."

If my neighbour sues me for assault because I grabbed her arm and marched her along, I will have a defence if the circumstances of the case are that she burst into my flat full of drugs and bad manners and refused to leave when I asked her. The law recognizes my right to use reasonable force to remove someone from my property. I would have no defence if I smashed her over the head with a bottle when this was all she had done. That degree of force would not be reasonable.

If the police charge me with assault occasioning bodily harm because I punched my boss in the face, splitting his lip and knocking out a tooth, I will have a defence if I can prove that he was attempting to rape me and I punched him to stun him and make my escape. I will not have a defence if I punched him because he sacked me. What the law regards as reasonable force, which justifies what would otherwise be an assault, is always decided on a case-bycase basis. It depends on the specific circumstances.

How can strip-searching, which is nothing other than an assault, be justified as "reasonable force" unless it is justified on the basis of specific and reasonable suspicion that the particular person about to be searched has contraband secreted on her person? To go on strip-searching women again and again without finding contraband cannot be justified. To strip-search women when 
there is no reason to suspect they are carrying contraband cannot be justified. The prisoner having received a visit is not "a reason."

\section{Strip-Searching as Abuse}

Strip-searching women is particularly abusive in the light of the preimprisonment experience of women prisoners. Research shows that 89 percent of women prisoners have been sexually abused. ${ }^{4}$ A survey conducted in 1989 by Women's House in Brisbane found that $70-80$ percent of women in prison were survivors of incest. A 1992 Australia-wide survey ${ }^{5}$ showed that of the 2,762 rapes $^{6}$ reported by women to the researchers, 43 percent of survivors were aged 16 or under at the time of the rape; 15.7 percent of survivors were aged $0-10$ at the time of the rape and of this group, 47.8 percent of the perpetrators were family members and 14.3 percent were acquaintances; 27.2 percent of the survivors were aged $11-16$ at the time of the rape and for this group, 16.7 percent of rapists were family members while only 22 percent were strangers.

The picture painted by these statistics is that survivors of sexual abuse are overrepresented in the prison population and that the overwhelming majority of women prisoners are survivors of sexual abuse. Significant numbers of women prisoners were abused as children by people in positions of authority or trust. It is cruel and inhuman treatment to revictimize these women by subjecting them to routine, random, or mandatory strip-searches by people who exert considerable authority and control over them and their lives.

But the state's deliberate demoralization of women prisoners is not merely found in the indignity and humiliation of the strip-search. On the one hand, women prisoners have access to sexual abuse counselling, psychiatric assistance for depression and other mental illness, and programs to improve their selfesteem and develop cognitive and assertiveness skills. On the other hand, a strip-search is the price the prisoner must pay to get a visit from her children,

\section{Supra 2.}

5 Patricia Easteal, "Survivors of Sexual Assault: A National Survey," in Easteal, P. (ed.), Without Consent: Confronting Adult Sexual Violence, pp. 74-91. Canberra: Australia Institute of Criminology, 1992.

6. For the purpose of survey, rape was defined as penetration of the vagina, anus, or mouth by any body part of the attacker or object used by the attacker without the consent of the victim. 
her lover, her mother. The deliberate cruelty is in the stripping away of any fragile self-esteem that might be developed by the various welfare programs conducted in prison. The total powerlessness and humiliation experienced by strip-searching can only exacerbate depression, thoughts of suicide, and incidents of self-mutilation and, ironically, return women to the need for drugs to avoid the mental anguish inflicted by abusive treatment. ${ }^{\text {? }}$

Another aspect of the impact of mandatory strip-searches reported to Sisters Inside is that some prisoners are now reluctant to receive visits - because the powerlessness and degradation experienced in the strip-search and the inevitable reminders of previous sexual abuse they invoke make these searches too much to take. Demanding a strip-search as the price of a family visit sounds like torture. Demanding a strip-search as the price for receiving a legal visit sounds like a concerted attempt to deny a prisoner's access to justice.

\section{International Law, Human Rights, AND Principles of IMPRISONMENT}

In Queensland, women prisoners are held in conditions and subjected to treatment that breaches United Nations standards and Australia's obligations under international law. Some of these standards and principles are binding on Australian governments, including the Queensland government, because they are found in treaties ratified by Australia and enacted in domestic law. Others may not have the binding force of law, but they are highly persuasive in their moral force because they have been declared by the United Nations General Assembly or formulated by official United Nations bodies.

International Covenant on Civil and Political Rights (referred to as the ICCPR) in force in Australia from November 13, 1980

Two relevant international treaties ratified by Australia and in force in Australian law are:

7 In a study of 100 women in South East Queensland Prisons surveyed by Sisters Inside, 42 percent of the women have attempted suicide (with a total of 50 attempts spread through the group); 41 percent have self-harmed (with a total of 331 self-harm experiences); 40 percent received no support; 23 percent believed the self-harm and attempted suicides were due to the abuse they had experienced. 
1. Convention on Elimination of All Forms of Discrimination against Women in force in Australia since August 27, 1983. There is no right of individual petition.

2. Convention against Torture and Other Cruel Inhuman or Degrading Punishment or Treatment (referred to as the Convention Against Torture) in force in Australia since September 7, 1988. "Communications" can be made to the UN Committee against Torture by other national governments or by individuals, and acts of torture have been made criminal offences in Australia by the Crimes (Torture) Act 1988 Cth.

\title{
Prisoners' Human Rights
}

\begin{abstract}
"All persons deprived of their liberty shall be treated with humanity and respect for the inherent dignity of the human person." (Article 10.1 ICCPR)
\end{abstract}

"No one shall be subjected to torture or to cruel, inhuman or degrading treatment or punishment." (Article 7 ICCPR)

Further, the Convention against Torture not only requires that Australia make torture a criminal offence (which it has done) but also requires Australia to prevent acts of cruel, inhuman, or degrading treatment or punishment done with the consent or acquiescence of any public official in the country.

"No one shall be subjected to arbitrary and unlawful interference with his privacy, family, home or correspondence ..." (Article 17.1 ICCPR)

"Everyone has the right to protection of the law against such interference or attacks." (Article 17.2 ICCPR)

The first part of this submission characterizes random or routine strip-searches of women prisoners as unlawful assaults verging on systemic sexual assault. The enormity of these assaults is exacerbated by the fact that the overwhelming majority of women prisoners are survivors of sexual abuse and incest. Stripsearches revictimize these women. 
Sisters Inside submits that routine or random strip-searching of women prisoners - that is, any searches other than those conducted on the basis of specific and reasonable suspicion of the individual about to be searched violates these provisions of the ICCPR and the Convention against Torture. Sisters Inside submits that random or routine strip-searching constitutes cruel, inhuman, or degrading treatment or punishment and as such is an arbitrary and unlawful interference with the privacy of the prisoner. Routine or random strip-searching violates the obligation to treat prisoners with humanity and respect for the inherent dignity of the human person. That violation itself makes it useful to the state as a means of social control.

The U.S. Supreme Court has considered the prohibition against cruel and unusual punishment in the Eighth Amendment of the U.S. Constitution and has held that such punishment includes more than just physically barbarous punishment. In Weems v. United States 217 U.S. 349 (1910) the Court observed that the prohibition against cruel punishment was not confined to punishment involving torture or lingering death, but acquires wider meaning as public opinion becomes enlightened by humane justice. In Estelle v. Gamble 429 U.S. 97 (1976) the Court held that the prohibition embodies broad and idealistic concepts of dignity and civilized standards of humanity and decency against which penal measures must be evaluated.

In Jordan v. Gardner 986 F.2d (9th Cir. 1993) the Court declared that "pat searches" of women prisoners by male guards amounted to cruel and unusual punishment. The judge said that intrusive probing searches by men in positions of ultimate authority constitute and reinforce gender subordination and offend our concepts of human dignity whether or not the woman prisoner had been sexually abused prior to imprisonment.

A punishment is cruel if it makes no measurable contribution to acceptable goals and hence is nothing more than the purposeless and needless imposition of pain and suffering. One indicator of cruel punishment is where the permissible aims of punishment (deterrence, isolation to protect the community and rehabilitation) can be achieved as effectively by punishing the offence less severely. ${ }^{8}$

Sisters Inside is of the view that routine and random strip-searching is conducted in order to punish women and to control them. Even if one accepts

8 Paul Sieghart, The International Law of Human Rights. (1983) Clarendon Press, p. 166. 
the Corrective Services' assertion that its purpose is to stop the entry of drugs into the prison, it has been pointed out earlier that it does not achieve this. It is cruel treatment even if it cannot be said that it is cruel punishment.

In Denmark et al. v. Greece the European Commission of Human Rights (EUCM) stated that the notion of inhuman treatment covers at least such treatment that deliberately causes severe suffering, mental or physical, which in the particular situations is unjustifiable. In Ireland v. United Kingdom the Commission noted that its use of the word "unjustifiable" had given rise to misunderstanding, as it did not have in mind the possibility that there could be a justification for the infliction of inhuman treatment. In Denmark et al. $v$. Greece the EUCM defined "degrading treatment" as treatment that grossly humiliates an individual or drives him to act against his will or conscience. In Europe, treatment has been held to be degrading in a number of cases - denial of exercise to prisoners whether convicted or on remand, taking a person through the town wearing handcuffs and prison dress, close body searches, the forced administration of medicine to a mentally abnormal prisoner. ${ }^{9}$

In Tyrerv. United Kingdom ([A/26]: [1979-1980]2 EHRR 1.) the European Court of Human Rights (EUCT) held that punishment does not lose its degrading character merely because it is believed to be, or actually is, an effective deterrent or an aid to crime control. The EUCT also held that while publicity might be a relevant factor in assessing whether a punishment is degrading, it might well suffice that the victim is humiliated in his or her own eyes.

Subjecting a woman prisoner to a strip-search other than one based on specific and reasonable suspicion of a criminal offence constitutes and reinforces her powerlessness and loss of dignity. It is inhuman and degrading treatment. Imposing strip-searches as the price a prisoner pays for visits from family, friends, and lawyers verges on torture. The Department of Corrective Services is in breach of Australia's obligations under the ICCPR and the Convention against Torture.

It can also be argued that arbitrary, capricious, and oppressive stripsearching of women is in breach of Australia's commitment to the rights of women. The Convention on the Elimination of All Forms of Discrimination against Women establishes the Committee on the Elimination of Discrimination 
against Women. The Committee comprises 23 experts of high moral standing and competence in the fields covered by the Convention. It has said that the definition of discrimination against women that is prohibited by the Convention includes gender-based violence; that is, violence that is directed against a woman because she is a woman or that affects women disproportionately.

A strip-search or intrusive "pat search" of breasts and genitals is an act of personal violence. In Queensland women prisoners are strip-searched more frequently than male prisoners. The former general manager stated that the reason for this is that women have more orifices in which they can conceal things. This is violence directed against women because they are women. If a woman is intrusively searched through in a position of ultimate authority, the search reinforces gender subordination in the most humiliating manner. This is violence that affects women disproportionately. As most women prisoners are survivors of sexual abuse, intrusive body searching that triggers recollections of prior abuse is violence that affects women disproportionately.

\section{Strip-Searching as Punishment}

Two important principles emerge from the international standards on the treatment of prisoners. First, individuals are sent to prison as punishment, not for punishment and second, justice does not stop at the prison door. ${ }^{10}$ While the law does take [the prisoner's] liberty and imposes a duty of servitude and observance of discipline for [her] regulation and that of other prisoners, it does not deny [her] right to personal security against unlaw ful invasion. ${ }^{11}$

The experience of women in Queensland prisons is that they are indeed sent to prison for punishment. They are regularly punished through routine and random strip-searching conducted because they are women, and because they are seen as a class of people who deserve no better treatment. Random and routine strip-searching violates the prisoner's right to personal security against unlawful invasion. The injustice perpetrated against women prisoners in the name of the state diminishes us all.

10 Nick O'Neill and Robin Handley, Retreat from Injustice: Human Rights in Austratian Law. (1994) Federation Press, p. 171.

1 Coffin v. Reichard 143 F. 2 d. 443 (1944) at p. 445. 


\section{PRINCIPLES OF IMPRISONMENT}

"The penitentiary system shall comprise treatment of prisoners, the essential aim of which shall be their reformation and social rehabilitation." (Article 10.3 ICCPR)

It is obvious that the humiliation and degradation caused by strip-searching is counterproductive to the reformation and social rehabilitation of women prisoners. Any gains achieved by running welfare programs designed to improve the mental health, self-esteem, and assertiveness and cognitive skills of women prisoners are seriously undermined by arbitrary strip-searching. Strip-searching can only be justified on the basis of specific and reasonable suspicion.

Maintenance of strong family ties during imprisonment, particularly with children, is widely recognized as an important element of rehabilitation that decreases recidivism. ${ }^{12}$ Because women in the new prison at Wacol face stripsearching as the price they must pay for a visit from family members, some women are now telling their families not to visit. This is not in the interests of their rehabilitation.

Almost 60 years ago in the United States, a court recognized that giving women prisoners a living environment free from the presence of males in positions of authority was necessary to foster the goal of rehabilitation, particularly in light of the fact that many of the prisoners had been physically and sexually abused by men. The prison governor's decision to exclude men from positions of authority was held not to be discriminatory. ${ }^{13}$

Australia is not only bound by Article 10.3 of the ICCPR; all Australian governments should also have strong regard to other United Nations' standards, such as the Body of Principles for the Protection of All Persons under any Form of Detention or Imprisonment, and the Standard Minimum Rules for the Treatment of Prisoners. Rule 53(2) of the Standard Minimum Rules states that women prisoners shall be attended to and supervised only by women officers. This does not preclude male members of staff, particularly doctors and teachers, from carrying out professional duties in institutions for women.

12 Amnesty International Report, AMR 51/01/99 United States of America. "Not Part of My Sentence." Violations of Haman Rights of Women in Custody, pp. 24-25.

13 Coffin v. Reichard 143 F. 2d. 443 (1944) at p. 445. 
The need for female-only correctional staff, other than professional staff such as doctors and teachers, is imperative in light of the cruel and damaging impact of strip-searches on women prisoners. However, the problem is not just male correctional officers conducting or observing strip-searches. The new women's prison at Wacol now has a system of 24-hour routine camera surveillance of prisoners. Frequent, close-up, and prolonged viewing by men of women showering, dressing, and using toilet facilities is humiliating and degrading. It violates the prohibition against cruel, inhuman, and degrading punishment or treatment. Again this runs counter to the requirement that imprisonment be rehabilitative.

It is nonsense to assert that the Anti-Discrimination Act (Queensland) prohibits the employment of female-only correctional officers. With respect to discrimination in employment, s. 24 of the Act provides that it is not unlawful to discriminate in the work area if an exemption in ss. 25-36 applies. Section 25 provides that a person may impose a genuine occupational requirement for a position. That men should not be employed as correctional officers in women's prisons is a genuine occupational requirement on a number of grounds. These range from Australia's obligations under international law and its commitment to international standards, the rehabilitative purpose of imprisonment, and the preponderance of survivors of male violence and abuse in the female prison population.

It cannot be further argued that excluding men from the ranks of correctional officers supervising and controlling women prisoners breaches $\mathrm{s}$. 101 of the Anti-Discrimination Act, which prohibits discrimination in the administration of state laws and programmes. Under s. 103 it is not unlawful to discriminate if an exemption in ss. 104-113 applies. Section 104 provides the relevant exemption - a person may act to benefit the members of a group of people with an attribute for whose welfare the act was designed if the purpose of the action is not inconsistent with the Anti-Discrimination Act. The examples given in s. 104 demonstrate that it is not unlawful to restrict special accommodation to women who have been victims of domestic violence or to establish a high security car park exclusively for women that would reduce the likelihood of physical attack.

It might be acceptable to employ men in low-security facilities for women where there is not routine intrusive viewing and searching of women. In lowsecurity facilities it is desirable that the difference between prison life and outside life be minimized in order to enhance rehabilitation. 


\section{Crisis Support UnIT}

This is another area where the common practice of strip-searching is used. Women are strip-searched three times a day in the Crisis Support Unit (CSU). A stated objective for the CSU is to provide for a safe and secure environment for prisoners who are actually suicidal or who have engaged in self-harming behaviour.

Women incarcerated in the new prison at Wacol are sent to the CSU at Moreton. The CSU is staffed by men and also accommodates male prisoners. Forms of restraint carried out in the CSU include forcible stripping and hogtying of prisoners by the male staff. In the first part of this submission it was pointed out that 89 percent of women prisoners are survivors of sexual abuse (probably 100 percent of those who mutilate themselves are survivors of sexual abuse), and that direct physical control of women prisoners by men in authority over them reinforces gender subordination and is humiliating and psychologically damaging to the women. Such direct physical control can constitute genderbased violence because it is violence that affects women disproportionately, particularly in the circumstances of women's pre-imprisonment experience.

The Crisis Support Unit does not necessarily provide a safe and secure environment for women prisoners who are actually suicidal or who have engaged in self-harming behaviour. Under no circumstances should a woman prisoner be accommodated in the Crisis Support Unit.

Debbie Kilroy is Director of Sisters Inside Inc. She can be contacted at P. O. Box 3407, South Brisbane, Queensland 4104, Australia. 